\title{
Concomitant Medication Active Ingredient
}

National Cancer Institute

\section{Source}

National Cancer Institute. Concomitant Medication Active Ingredient. NCI Thesaurus.

Code C83014.

The pharmaceutically active ing redients of the concomitant medication. 